\title{
PHENOTYPIC CHARACTERIZATION OF VIRUIENT AND ANTIMICROBiAL RESISTANT SALMONELLA SPECIES ISOLATED FROM POULTRY
}

\author{
Amira F. Ibrahim ${ }^{1}$; Ahmed M. A. Ammar ${ }^{2}$; Ibrahim E. El-dosoky .; \\ Heba A. Ahmed ${ }^{4}$. and Soad A. Nasef ${ }^{5}$ \\ ${ }^{1}$ Reference laboratory for vet. Quality Control on poultry production, \\ Animal Health Research Inst., (Dakahlia Branch) \\ ${ }^{2}$ Bacteriology, Mycology and Immunology Dept. Fac.Vet. Med., \\ Zagazig University., Egypt \\ ${ }^{3}$ Bacteriology, Mycology and Immunology Dept. Fac. Vet. Med., \\ Kafrelsheikh University, Egypt \\ ${ }^{4}$ Zoonoses, Dept. Fac. Vet. Med., Zagazig University., Egypt \\ ${ }^{5}$ Reference laboratory for vet. Quality Control on poultry production, \\ Animal Health Research Inst., Dokki, Giza
}

\begin{abstract}
Pathogenesis of Salmonellosis depends upon a large number of factors controlled by an array of genes that synergise into the actual virulence of Salmonella. In the present study, out of 730 samples collected from different poultry farms located in Dakahlia province, Egypt, Salmonella spp were identified in 12\%, $8.6 \%$ and $3.8 \%$ of ducks, chickens and quails respectively. Serological identification showed that the high percentage of isolation was for S. Typhimurium (32.5\%) and S. Newport (14\%) in chickens, S. Infantis (25\%) in ducks and S. Shangani (60\%) in quails. Salmonella serovars showed $100 \%$ pathogenicity using Embryo lethality assay. The isolated Salmonella serovars were $100 \%$ susceptible to only Amikacin and highly resistant to Flumequine, Nalidixic acid, Oxytetracycline, Ampicillin/Sulbctam, Amoxicillin and Trimethoprim-Sulfamethoxazole with the percentages of $90 \%, 86.7 \%, 73.3 \%, 73.3 \%, 68.3 \%$ and $58.3 \%$ respectively. The obtained results confirm the need for a country adherence to strict public health and food safety regimes.
\end{abstract}

Keywords: Salmonella, Virulence gene, Antibiotic resistance, Poultry. 


\section{INTRODUCTION}

Over the last 20 years, the results from DNA relatedness studies have indicated that all Salmonella serotypes are probably a single bacteria that is called Salmonella enterica (Bell and Kyriakides, 2002). Seven subspecies have been identified within the species. The subspecies enterica is of most concern because more than $99 \%$ of Salmonella isolated from humans belong to this subspecies (Old, 1992).

Different virulence phenotypic assays have been used for the analysis of microbial virulence. For instance, the chicken embryo lethality assay (ELA) is a relatively simple and inexpensive test to predict virulence from death of embryos (Seo et al., 2013). Also, biofilm assay is defined as an organized bacterial community adhered to a biotic surfaces and biotic layers with a matrix of exopolysaccharide (EPS) (Costerton et al., 1995). The biofilm formation of food-borne pathogens has attracted much attention in the medical field and food industry due to its potential risks, including antimicrobial resistance and virulence factor production.

The emergence of antibiotic resistant strains, due to the therapeutic use of antibiotics in animals including poultry, is a future threat to human health (Forshell and Wierup, 2006). Both the antibiotic resistance and virulence factors are required by the organism for survival against the host defenses.

Consequently, the objectives of the current study were to determine and establish baseline data on the prevalence of $S$. enterica serovars, phenotypic detection of virulent and antibiotic-resistant Salmonella phenotypes originated from various sources (chicken, duck, and quail) in Egypt. 


\section{MATERIAL AND METHODS}

\section{Sample collection:}

A total of 730 samples were aseptically collected from poultry farms, houses and markets at Dakahlia Governorate. The samples comprised of 500 chicken samples (200 dropping, 90 livers, 110 spleen and 100 cecal samples), 100 duck samples (60 dropping and 40 livers samples) and 130 quail samples (80 dropping and 50 livers samples).

\section{Isolation, identification and serotyping of Salmonellae:}

The isolation and identification of Salmonellae were done according to ISO $6579(2002,2007)$ method. Colonies that showed typical colonial appearance were subjected to biochemical identification using oxidase test, hydrolysis of urea, $\mathrm{H}_{2} \mathrm{~S}$ production and lysine decarboxylation (Cruickshank et al., 1975). Strains were serotyped following KauffmanWhite Scheme (Kauffman, 1974) with commercial antisera (Difco Laboratories Deteroeit, Mitchigeu, USA) for somatic (O) and flagellar (H) antigen identification. Serotyping was performed at Animal Health Research Institute, Doki, Giza.

\section{Chick embryo lethality assay:}

A total of 150 specific-pathogen-free embryonated eggs were used for the assay. Five eggs were kept as a control group and for each isolate, five eggs were inoculated and incubated in a $37^{\circ} \mathrm{C}$ humidified egg incubator according to Nolan et al. (1992). A dilution of the McF\#1 equivalent was used to inoculate 10-12 day old embryos by injecting $0.1 \mathrm{ml}$ into the chorioallantoic sac (CAS). All inoculated embryos were sealed, incubated and candled daily, for any lethality through their 18th day of age (Wooley 
et al., 2000). Each time an assay was run, 5 additional 12 day old embryos of the same setting were inoculated with $0.1 \mathrm{ml}$ of TPB by the same route. Any test in which more than one negative control embryo died during the assay period was considered invalid and was repeated. According to Wooley et al. (2000), virulence groups were based on death rates and included avirulent $(<10 \%)$, moderately virulent (10-29\%), and virulent $(>29 \%)$.

\section{Biofilm formation:}

A loopful from each of isolated Salmonella spp was inoculated separately in $5 \mathrm{ml} \mathrm{LB}$ broth without salt and one tube remain un inoculated as negative control then Biofilm formation was visualized after 96 hours according to Turki et al. (2014). The inoculated broth was discarded carefully, stained with crystal violet $1 \%$ for 15 minute and then the stain was discarded.

\section{Determination of antimicrobial drug resistance:}

Determination of the susceptibility of the isolated strains to different antibiotics was adopted using the disc diffusion technique according to NCCLS (2008). The antimicrobial agents and corresponding concentrations used in this study included Ampicillin/Sulbctam (20 mg), Amoxicillin (10 $\mathrm{mg}$ ), Gentamicin (10 mg), Neomycin(30mg), Streptomycin (10 mg), Amikacin (30 mg), Flumequine (30 mg), Nalidixic acid (30 mg), Ciprofloxacin (5mg), Enrofloxacine (5mg), Norfloxacin (10 mg), levofloxacin (5 mg), chloramphenicol (30 mg), Cefotaxime (30 mg), Ceftriaxone (30 mg), Ceftazidime (30 mg), Oxytetracycline (30 mg), and Sulphamethoxazolez-trimethoprim (25 mg). 


\section{RESULTS}

\section{The overall isolation rate of Salmonella spp. in the examined samples:}

According to the phenotypic identification of Salmonella spp., the results show that the overall isolation rate of Salmonella spp. was $8.6 \%$, $12 \%$ and $3.8 \%$ in chicken, ducks and quails, respectively. In chicken, the isolation rates of Salmonella spp. from liver, dropping, cecal parts and spleen were $12.2 \%, 9 \%, 8 \%$ and $4.5 \%$, respectively. In ducks, Salmonella spp. were detected in dropping and liver samples with the respective isolation rates of $13.3 \%$ and $10 \%$. Finally, in quails, the occurrence of salmonellae in dropping and liver samples was $4 \%$ and $3.8 \%$, respectively.

\section{Salmonella serotypes identified in examined samples:}

A total of 60 strains of Salmonella spp. were isolated from all the examined samples. These isolates were serotyped by using polyvalent and monovalent "O" and "H" antisera. The highest percentage in chickens was for $S$. Typhimurium (32.5\%), followed by $S$. Newport and $S$. Kentucty with isolation rates of $14 \%$ and $9.3 \%$, respectively. $S$. Molade and $S$. Tamale were identified with the percentage of $7 \%$, each. Also, $S$. Magherafelt and $S$. Enteritidis were recovered with the percentage of $4.7 \%$, each. Moreover, $S$. Apeyeme, $S$. Colindale, $S$. Papuna, $S$. Shubra, $S$. Lexington, $S$. Labadi, $S$. Takoradi, $S$. Rechovot in addition to one Untypable strain comprised $2.3 \%$, each, out of the identified isolates. $S$. Infantis was recovered from duck samples with the percentage of $25 \%$, while, $S$. Inganda and $S$. Virchow were identified with the percentage of $16.6 \%$, each. $S$. Larochelle and $S$. Vejle were detected from $8.3 \%$ of the isolates, each, in addition to three untypable strains (25\%, each). In quail samples, $S$. Shangani was identified from $60 \%$ of the isolates, while $S$. Wingrove and $S$. Alfort were detected with the percentage of $20 \%$, each (Table 1). 
Amira F. Ibrahim, et., al.

Table (1): The overall isolation rates of Salmonella serotypes isolated from the examined flocks.

\begin{tabular}{|c|c|c|c|c|}
\hline \multirow{2}{*}{$\begin{array}{l}\text { Types of } \\
\text { flocks }\end{array}$} & \multirow{2}{*}{$\begin{array}{c}\text { Salmonella } \\
\text { positive }\end{array}$} & \multicolumn{3}{|c|}{ The isolated serotypes } \\
\hline & & Salmonella serotypes & $\begin{array}{c}\text { No. of } \\
\text { serotypes }\end{array}$ & $\begin{array}{c}\text { proportion } \\
(95 \% \mathrm{CI})\end{array}$ \\
\hline chicken & 43 & $\begin{array}{c}\text { S. Typhimurium } \\
S . \text { Newport } \\
S . \text { Kentucky } \\
S . \text { Molade } \\
S . \text { Tamale } \\
S . \text { Magherafelt } \\
S \text {. Enteritidis } \\
\text { S. Apeyeme } \\
S . \text { Colindale } \\
S . \text { Papuna } \\
S . \text { Shubra } \\
S . \text { Lexington } \\
S . \text { Labadi } \\
S . \text { Takoradi } \\
S . \text { Rechovot } \\
\text { Untypable } \\
\end{array}$ & $\begin{array}{l}14 \\
6 \\
4 \\
3 \\
3 \\
2 \\
2 \\
1 \\
1 \\
1 \\
1 \\
1 \\
1 \\
1 \\
1 \\
1 \\
\end{array}$ & $\begin{array}{l}32.5 \\
14.0 \\
9.3 \\
7.0 \\
7.0 \\
4.7 \\
4.7 \\
2.3 \\
2.3 \\
2.3 \\
2.3 \\
2.3 \\
2.3 \\
2.3 \\
2.3 \\
2.3 \\
\end{array}$ \\
\hline Ducks & 12 & $\begin{array}{c}S . \text { Infantis } \\
S . \text { Virchow } \\
S . \text { Inganda } \\
S . \text { Larochelle } \\
S . \text { Vejle } \\
\text { Untypable }\end{array}$ & $\begin{array}{l}3 \\
2 \\
2 \\
1 \\
1 \\
3\end{array}$ & $\begin{array}{c}25 \\
16.6 \\
16.6 \\
8.3 \\
8.3 \\
25 \\
\end{array}$ \\
\hline Quails & 5 & $\begin{array}{l}S . \text { Shangani } \\
S . \text { Wingrove } \\
S . \text { Alfort }\end{array}$ & $\begin{array}{l}3 \\
1 \\
1 \\
\end{array}$ & $\begin{array}{l}60 \\
20 \\
20 \\
\end{array}$ \\
\hline Total & 60 & & 60 & 8.4 \\
\hline
\end{tabular}

\section{Determination of antimicrobial drug resistance:}

The resistance pattern of the identified 60 Salmonella isolates was determined against a range of antimicrobials that are commonly used in treating and preventing Salmonella infection in poultry. Antibiotic sensitivity testing of Salmonella isolates revealed that resistance rates to the Aminogycoides were 56.7\%, 38.3\% and 23.3\% against Streptomycin, Neomycin, and Gentamycin, respectively, while no resistance was recorded for Amikacin. The respective resistance rates of the isolates to $\beta$-lactams Penicillins (amoxicillin) and $\beta$-lactams inhibitors (Ampicillin/Sulbctam) were $68.3 \%$ and $73.3 \%$. In case of $\beta$-lactams cephalosporins (Ceftriaxone, 
Ceftazidim and Cefotaxim), resistance rates of $28.3 \%, 20 \%$ and $11.7 \%$ respectively, were observed. Resistance to Flumequine (90\%), Nalidixic acid $(86.7 \%)$, Enrofloxacine (41.7\%), Ciprofloxacin (25.0\%), Norfloxacin (16.7\%) and levofloxacin (8.3\%) and Oxytetracycline $(73.3 \%)$ was also notable.

\section{Pathogenicity of Salmonella serovars isolated from different samples (Chicken embryo lethality assay):}

A number of 29 Salmonella isolates that showed multiple drug resistance were chosen for determining their pathogenicity using chicken embryo lethality assay. Using the lethality system described by Wooley et al. (2000), all of the isolates (29/29) were primary pathogens with mortality rates $>29 \%$.

\section{Biofilm formation by Salmonella spp:}

The results revealed that, all the examined Salmonella isolates had the ability to make biofilms on the inner walls of the glass tubes after crystal violet staining. However, no biofilm was observed with the negative control.

\section{DISCUSSION}

Salmonella infection is one of the most important bacterial diseases in poultry causing heavy economic loss through mortality and reduced production (Haider et al., 2004).

The obtained results in the current study showed that on examination of 500 chicken samples, Salmonella species were isolated with an overall percentage of $8.6 \%$. Nearly similar results were obtained by Draz et al. (1996) who reported $11.4 \%$ of Salmonella species from living layer flocks 
in poultry farms in Alexandria province. However, lower isolation rate of 2.5\% was reported by Mohamed et al. (1999) who isolated Salmonellae from chicken farms in Kafr-Elsheikh.

In ducks, Salmonellae were isolated from $12 \%$ of the examined samples. Nearly similar results were obtained by Hoszowski and Wasyl (2005) who detected Salmonella in duck broilers with the percentage of $14.3 \%$ in Poland. Higher isolation rate was reported in Egypt by El-Sayed (2014) who recorded $36 \%$ of Salmonella species in internal organs and paper lining boxes of imported ducks.

In the current study, Salmonellae were isolated from $3.8 \%$ of the examined quails. Isolation rates of Salmonella spp. from quails in other countries were reported to vary from zero in Poland (Radkowski, 2001) and $1.8 \%$ in India (Suresh et al., 2006) to $40 \%$ in Iran (Jalali et al., 2008) and $75 \%$ in São Paulo, Brazil (Freitas et al., 2013).

The difference in Salmonella prevalence from area to another could be related to hygienic measures in each area, season of conducting the study and the area of collection itself.

The obtained results showed that 23 serotypes of Salmonellae were identified with $S$. Typhimurium predominating, this was in agreement with Murugkar et al. (2005) who isolated S. Typhimurium from $35.2 \%$ of diarrhoeic birds in India. Lower percentage of $S$. Typhimurium (6.7\%) was recorded by Orji et al. (2005). Moreover, S. Newport (2\%) was reported by Melendez et al. (2010).

Salmonella species have been recognized as human and animal pathogens for over a century. Numerous serotypes had been described, but seven of these (Enteritidis; Typhimurium; Newport; Javiana; Heidelberg; 
Montevideo) were responsible for $61.6 \%$ of human cases in the U.S. in 2007 (Doyle et al., 2009). The most common Salmonella serovars associated with gastroenteritis were $S$. Typhimurium and $S$. Enteriditis with other serovars such as $S$. Infantis being implicated but at much lower frequencies (Calenge et al., 2010).

The increased level of antimicrobial resistance observed in Salmonellae has become a public health issue. The development of resistance in Salmonellae to antimicrobial agents is attributable to one of several mechanisms such as production of enzymes that inactivate antimicrobial agents through degradation or structural modification, reduction of bacterial cell permeability to antibiotics, activation of antimicrobial efflux pumps, and modification of cellular drug targets (Sefton, 2002). The results of the current study were nearly similar to the

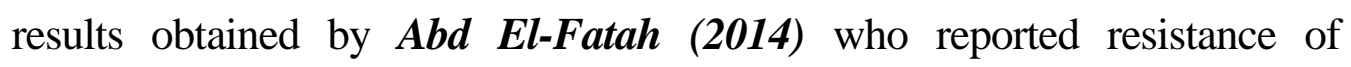
Salmonella strains recovered from chicken to Nalidixic acid (67.7\%), Norfloxacin (17.6\%), ciprofloxacin (5.9\%) and Levofloxacin (2.9\%). On the contrary, Parvathi et al. (2011) recorded that resistance rates of Salmonella isolates to different antimicrobials were, $25 \%$ to Ampicillin, $23.3 \%$ to Tetracycline, $31.6 \%$ to Trimethoprim/sulfamethoxazole, $15 \%$ to Ciprofloxacin, $15 \%$ each to Cephalothin and Cephalexin, $23.5 \%$ to Nalidixic acid and $15 \%$ to Chloramphenicol.

Using the lethality assay, all of the isolates (29/29) were primary pathogens with mortality rates $>29 \%$. These findings are in agreement with El-Sayed (2014) who found that the lethality of embryos through their 19 day of inoculation was $100 \%$, indicating highly pathogenic isolates. Moreover, Osman et al. (2014) recorded $100 \%$ death of the embryos during the periods of day-13 and day-17. 
The current results showed that all the isolated Salmonellae were able to form a biofilm. These results are matching with Turki et al. (2012) who found that the majority of strains tested were able to form a biofilm, especially for environmental and animal derived isolates. However, other reported studies showed that 33.5\% (Turki et al., 2014) and 54.54\% (Abdallah et al., 2014) of Salmonella enterica isolates were able to form biofilm.

\section{CONCLUSION}

Finally, Salmonellae with multiple antibiotic resistance and virulence determinants are becoming more and more widespread, with a growing socioeconomic impact. There is a need to intensify campaigns for reducing use of antibiotics and common therapeutic protocols. Constant monitoring of pathogens with an impact on public health is also necessary in order to enable the competent authorities to activate effective, specific surveillance and control plans.

\section{REFERENCES}

- Abdallah, F. B.; Lagha, R.; Said, K.; kallel, H.; Gharbi, J (2014): Detection of Cell Surface Hydrophobicity, Biofilm and Fimbirae Genes in Salmonella Isolated from Tunisian Clinical and Poultry meat. Iranian J Publ Health., 43(4): 423-431.

- Abd El-Fatah, A. A. M. (2014): Detection of multidrug resistant Salmonellae. M. V. Sc. Thesis, Fac. Vet. Med. Microbiology Department. Cairo University.

- Bell, C. and Kyriakides, A. (2002): Salmonella: A practical approach to the organism and its control in foods. Blackwell Science Ltd. Osney Mead, Oxford. 
- Calenge, F.; Kaiser, P.; Vignal, A. and Beaumont, C. (2010): Genetic control of resistance to salmonellosis and to Salmonella carrier-state in fowl. A Genet. Selection Evol., 42: 11.

- Costerton, J. W., Lewandowski, Z.; Caldwell, D. E.; Korber, D. R. and Lappin-Scott, H. M. (1995): Microbial biofilms. Annu. Rev. Microbiol. 49: 711-745.

- Cruickshank, R.; Duguid, J. P.; Marmion, B. P.; and Swain, R. H. A. (1975): Medical Microbiology. The Practice of Medical Microbiology. 12th Ed. Vol. II Churchill Living stone, Edinburgh, London and New York., 2:170-188.

- Doyle, M. E.; Kaspar, C.; Archer, J. and Klos, R. (2009): White Paper on human illness Caused by Salmonella from all Food and Non-Food Vectors. Food Research Institute, UW-Madison.

- Draz, A. A.; El-gohary, A. H. and Samahy, H. A. (1996): Environmental pollution with certain bacterial pathogens of zoonotic importance in some poultry farms. 7th Sci. Cong. Fac. Vet. Med. Assiut, Egypt.

- El-Sayed, Z. A. E. (2014): Bacteriological Studies on Salmonella Isolated form Imported One-day old Ducklings. M. V. Sc. Thesis, Fac. Vet. Med. Department of Microbiology. Cairo University.

- Forshell, L. P. and Wierup, M. (2006): Salmonella contamination: a significant 7challenge to the global marketing of animal food products. Rev. sci. tech. Off. int. Epiz., 25 (2): 541-554. 
- Freitas, N. O. C..; Angela, H. L..; Soares, N. M.; Guastalli, E. A. l.; Almeida, A. M.; Berchieri, J. (2013): Salmonella spp. in Meat-type Quails (Coturnix coturnix coturnix) in the State of São Paulo, Brazil. Brazilian Journal of Poultry Science. 15 (3): 169-286.

- Haider, M., Hossain, M., Hossain, M., Chowdhury, E., Das, P. and Hossain, M. (2004): Isolation and characterization of Enterobacteria Associated with Health and Disease in Sonali Chickens. Banganladesh Journal of Veterinary Medicine. 2 (1):15 - 21.

- Hoszowski, A. and Wasyl, D. (2005): Salmonella prevalence and resistance to antibiotics in Poland. Medycyna Weterynaryjna. 61: 6, 660-663.

- Iso 6579 (2002): Microbiology of food and animal feeding stuffs for detection of Salmonella.

- Iso 6579 (2007): Detection of Salmonella species in animal faeces and in environmental samples from the primary production stage.

- Jalali, M.; Abedi, D.; Pourbakhsh, S. A. and Ghokasin, K. (2008): Prevalence of Salmonella species in raw and cooked foods in Isfahan, Iran. J. of Foods Safety., 28 (3): 442-452.

- Kauffman, F. (1974): Serological diagnosis of Salmonella species. Kauffman White Scheme Minkagaord, Copenhagen, Denmark.

- Melendez, S. N.; Hanning, I.; Han, J.; Nayak, R.; Clement, A. R.; Wooming, A.; Hererra, P.; Jones, F. T.; Foley, S. L. Ricke, S. C. (2010): Salmonella enterica isolates from pasture-raised poultry exhibit antimicrobial resistance and class I integrons. Appl Microbiol., 109(6):1957-1966. 
- Mohamed, L. N.; Samaha, H. A.; Draz, A. A. and Haggag, Y. N. (1999): Salmonellae among birds and human beings. Alex. J. Vet. Sc., 15 (1): 147-154.

- Murugkar, H. V.; Rahman, H.; Ashok-Kumar. and Bhattacharya, D. (2005): Isolation, phage typing \& antibiogram of Salmonella from man\&animals in northeastern India. Indian J Med Res., 122:237-242.

- NCCLS; National committee for clinical standard. (2008): Methods for antimicrobial susceptibility testing of anaerobic bacteria, 2nd Ed NCCLS document M11-T2 Villanova. PA19085. USA.

- Nolan, I. K.; Wooley, R. E.; Brown, J.; Spears, K. R.; Dickerson, H. W. and Dekich, M. (1992): Comparison of a complement resistance test, a chicken embryo lethality test, and the chicken lethality test for determining virulence of avian Escherichia coli.Avian Dis.,36:395-397.

- Old, D. C. (1992): Nomenclature of Salmonella. J. Med. Microbiol., 37: $361-363$.

- Orji, M. U.; Onuigbo, H. C. and Mbata, T. I. (2005): Isolation of Salmonella from poultry droppings and other environmental sources in Awka, Nigeria. Int. J. Inf. Dis., 9: 86-89.

- Osman, K. M.; Marouf, S. H.; Zolnikov, T. R. and AlAtfeehy, N. (2014): Isolation and characterization of Salmonella enterica in dayold ducklings in Egypt. Pathogens and Global Health.,180(1): 37-48

- Parvathi, A.; Vijayan, J.; Murali, G.and Chandran, P. (2011): Comparative virulence genotyping and antimicrobial susceptibility profiling of environmental and clinical Salmonella enterica from Cochin, India. Curr. Microbiol., 62(1): 21-26. 
- Radkowski, M. (2001): Occurrence of Salmonella spp. in consumption eggs in Poland. Int. J. Food. Microbiol., 64: 189-191.

- Sefton, A. M. (2002): Mechanisms of antimicrobial resistance: Their clinical relevance in the new millennium. Drugs, 62: 557-566.

- Seo, H.; Cha, S.; M. Kang, M. and Jang, H. (2013): Chicken embryo lethality assay for determining the virulence of Riemerella anatipestifer isolates. Avian Pathology, 42(4): 387-392.

- Suresh, T.; Hetha, A. A. M.; Sreenivasan, D., Sangeetha, N. and Lashmanaperumalsamy, P. (2006): Prevalence and antimicrobial resistance of Salmonella Enteritidis and other Salmonellae in the eggs and egg-storing trays from retails markets of Coimbatore, South India. Food. Microbiol., 23: 294-299.

- Turki, Y.; Ouzari, H.; Mehri, I.; Aissa, R. B. and Hassen, A. (2012): Biofilm formation, virulence gene and multi-drug resistance in Salmonella Kentucky isolated in Tunisia. Food Res. Int., 45: 940-946.

- Turki, Y.; Mehri, I.; Ouzari, H.; Khessairi, A. and Hassen, A. (2014): Molecular typing, antibiotic resistance, virulence gene and biofilm formation of different Salmonella enterica serotypes. J. Gen. Appl. Microbiol., 60: 123-130

- Wooley, R. E.; Gibbs, P. S.; Brown, T. P. and Mauer, J. J. (2000): Chicken Embryo Lethality Assay for Determining the Virulence of Avian Escherichia coliIsolates. Avian Diseases., 44, 318-324. 


\section{الملخص العربى}

قدرة السالمونيلا على احداث مرض يعتمد على عدد كبير من العوامل التي تتحكم بها مجموعة من الجينات التي تضافر في الضراوة الفعلية للسالمونيلا .في هذه الدراسة، من أصل 730 العينات التي تم جمعها من مزارع الدواجن مختلفة تقع في محافظة الدقهلية فى مصر . قد وجدت السالمونيلا في 12\%، 8.6 و 3.8٪ من البط والدجاج والسمان على النقالي. وبعد عمل التصنيف السيرولوجى لها وجد ان اعلى نسبة عزل فى الدجاج كانت لسامونيلا تيفميوريوم (32.5\%) ثم نيوبورت (14.0\%) ولكن فى البط كان اعلى نسبة عزل لسالمونيلا انفانتيس (25.0\%) بينما فى السمان كان اعلى نسبة عزل لسالمونيلا شانجاى (60.0\%). بعد دراسة تأثثر المعزولات على اجنة البيض (SPF) وجد انها قتلت كل الاجنه على مدى اثنى عشرة يوم بعد الحقن. كما تم عمل اختبار لمعرفه قدرة السالمونيلا على عمل فيلم بيوكميائى ووجد انها كلها كانت قادرة على عمل الفيلم البيوكميائى. و قد كثفت عن وجود تفاونا في مقاومة العترات للمضادات الحيوية حيث كانت سلالات السالمونيلا المعزولة حساسه بنسبه 100\% للأميكاسين واظهرت مقاومة عالية للفلوميكوين، حمض النالدكسيك، أكسي تنتراسكلين، الأمبيسلين/سالبكتام، أموكسيسيلين وتريميثوبريم-سلفاميثوكسازول بنسب 90٪، 86.7٪، 73.3٪؛ 73.3\% 68.3\% و 58.3\% على التوالي .النتائج التي تم الحصول عليها تؤكد على ضرورة التقبد البلاد لأنظمة الصحة العامة وسلامة الأغذية الصارمة. 